\title{
Czynniki warunkujące rozwój przedsiębiorczości w małych i średnich przedsiębiorstwach
}

\author{
Magdalena Ratalewska*
}

Celem artykutu jest pokazanie jakie czynniki utrudniaja rozwój przedsiębiorczości w Polsce, jakie jej sprzyjaja i co wtadze lokalne moga zrobić by wesprzeć przedsiębiorczość na swoim terenie. W artykule ukazane sa ogólne kierunki dziatań, jakie rząd polski podejmuje by poprawić przedsiębiorczość polskich przedsiębiorstw. Jednocześnie wymienione sq bariery rozwoju przedsiębiorczości $w$ Polsce, które wg konfederacji pracodawców Lewiatan $w$ największym stopniu utrudniają rozwój przedsiębiorczości wśród krajowych firm. Na tym tle przedstawione sq wyniki badań firm z matego polskiego miasta, które pozwalaja zestawić spojrzenie na czynniki wspierające i utrudniajace rozwój biznesu z perspektywy lokalnych przedsiębiorców. Koncentracja uwagi na przedsiębiorczości, $w$ szczególności na matych i średnich przedsiębiorstwach jest zadaniem kluczowym dla rozwoju gospodarki kraju. Dane GUS wskazuja na to, że 99,8\% wszystkich zarejestrowanych przedsiębiorstw należy do sektora MŚP. Zalecenia jakie zostaty przedstawione $w$ artykule wynikaja z przeprowadzonych badań $w$ matym polskim mieście - Tomaszowie Mazowieckim na tamtejszych przedsiębiorcach. Ciekawym wnioskiem $z$ badań jest, że jedna z głównych trudności $w$ rozwoju przedsiębiorstw ankietowanych to brak wystarczających zasobów finansowych. Jednocześnie przedsiębiorcy ci posiadaja bardzo niewielka wiedze na temat wymogów i procedur przyznawania dofinansowania ze środków unijnych czy innych zewnętrznych źródet i przejawiają niewielkie zainteresowanie by tę wiedzę pozyskać.

Do głównych zadań stojacych przed wtadzami lokalnymi zaliczono dziatania zwiazane $z$ informowaniem $i$ udzielaniem wsparcia lokalnym przedsiębiorcom $w$ zakresie pozyskania środków finansowych na rozwój.

Słowa kluczowe: przedsiębiorczość, innowacyjność, bariery rozwoju, sektor MŚP.

Nadesłany: 15.06.2014 | Zaakceptowany do druku: 13.08.2014

\section{Factors determining entrepreneurship development in small and medium enterprises}

The aim of this summary is showing factors, both obstructing and encouraging entrepreneurship development and what local authority can do to support it.

Concentration focused on small and medium enterprises is central importance for economy development. GUS data showing that 99,8\% all registered enterprises belong to SME sector. Prescriptions from this article has come from research among contractors in small polish townTomaszów Mazowiecki. Very interesting conclusion is the fact that luck of resources is the main difficulty in entrepreneurship development. Simultaneously, contractors' have small knowledge about requirements and procedure how to gain subsidy from European Union or other external sources. Moreover, they're not specially interested how to achieve needed knowledge.

\footnotetext{
Dr Magdalena Ratalewska - Uniwersytet Lódzki, Wydział Zarządzania, Katedra Przedsiębiorczości i Polityki Przemysłowej.

Adres do korespondencji: Uniwersytet Łódzki, Wydział Zarządzania, ul. Matejki 22/26, 90-237 Łódź; e-mail:mratalewska@uni.lodz.pl.
} 
Educating and supporting local contractors to gain the founds for developing are the main tasks for local authorities.

Keywords: Entrepreneurship, innovativeness, barriers to development, SME sector.

Submitted: 15.06.2014 | Accepted: 13.08.2014

JEL: L25, L26

\section{Pojęcie przedsiębiorczości}

Pojęcie przedsiębiorczości może być szeroko rozumiane. Wg Kortana przedsiębiorczość to sposób działania polegający na skłonności do podejmowania nowych, ryzykownych i niekonwencjonalnych przedsięwzięć oraz na wykazywaniu inicjatywy $\mathrm{w}$ ich poszukiwaniu i wdrażaniu w życie. Jest to więc działanie skierowane na rozwój i ma ono charakter innowatorski. W szczególności polega na (Kortan, 1997, s. 77, 78):

- tworzeniu bardziej efektywnych form organizacyjnych,

- wprowadzaniu nowych czynników produkcji,

- zdobywaniu nowych rynków zbytu i zaopatrzenia,

- wprowadzaniu nowych wyrobów.

W szerszym znaczeniu przedsiębiorczość to cecha, a ściślej zespół cech psychicznych warunkujących bycie dobrym przedsiębiorcą, tzn. osiąganie sukcesów w kierowaniu przedsiębiorstwem (Marek, 1998, s. 28).

Pojęcie przedsiębiorczości ukształtowało się na przełomie XVIII i XIX wieku. Było związane z rodzącym się kapitalizmem i erą rewolucji przemysłowej. Okres ten kształtował w społeczeństwie nowe postawy formowane przez kapitał, ekonomię, technikę. Pionierami poglądów na temat przedsiębiorczości byli A. Smith, J.B. Say i J. Schumpeter (Potocki, 2000, s. 19, 20).

Jednym z najczęściej omawianych w literaturze pionierów piszących o przedsiębiorczości jest wybitny austriacki ekonomista Joseph Schumpeter, który na początku XX wieku w swoich pracach wykazywał, że przedsiębiorca w rozwoju gospodarczym kraju odgrywa rolę szczególnie ważną. Polega ona według autora na „kreatywnej destrukcji”, czyli na zastępowaniu dotychczasowych zasad prowadzenia biznesu nowymi zasadami, co odbywa się poprzez wprowadzanie przez przedsiębiorców - innowatorów nowych produktów czy nowych technologii, które zmieniaja dotychczasowy układ sił obowiązujących w branży (Schumpeter, 1960, s. 64). Myśli Schumpetera ukonstytuowały pojęcie przedsiębiorczości jako zjawiska, które jest źródłem tworzenia się przełomowych zmian.

Rozwój gospodarczy na świecie, zwłaszcza za czasów Schumpetera, nie potwierdzał jednak założeń autora. Wiek XX charakteryzował się silną dynamiką rozwojową przede wszystkim dużych przedsiębiorstw, których siła wynikała z wielkości posiadanych zasobów, a w szczególności ze zjawiska ekonomii skali, czyli masowej produkcji, która pozwalała produkować taniej i sprzedawać za niższą cenę, niż mogli to zrobić mniejsi konkurencji. To przede wszystkim duże przedsiębiorstwa dokonywały „twórczej” destrukcji zmieniającej zasady gry w branżach.

Mimo to pojęcie przedsiębiorcy i przedsiębiorczości zaczęło cieszyć się coraz większą popularnością zarówno w nauce, jak i w praktyce. Badania nad przedsiębiorczościa prowadzone były nadal. W drugiej połowie XX wieku jednym $\mathrm{z}$ najważniejszych autorów piszących o zarządzaniu i przedsiębiorczości był Peter Drucker. Przy czym autor ten wyraźnie odróżniał pojęcie przedsiębiorcy od pojęcia właściciela firmy, pisząc: „Na pewno mąż i żona, którzy otwierają kolejne delikatesy czy następną restaurację meksykańską na amerykańskim przedmieściu podejmują ryzyko. Czy jednak są przedsiębiorcami? Robią tylko to, co wcześniej robiono już wiele razy. Spekulują na temat rosnaccej popularności jedzenia poza domem w swojej okolicy, lecz nie tworzą ani nowego popytu konsumenckiego, ani sposobu jego zaspokojenia. Patrząc z tej perspektywy, z pewnościa nie sa przedsiębiorcami, mimo że ich przedsięwzięcie jest nowe" (Drucker, 1992, s. 30)

Kierunek tego myślenia zyskał akceptację w świecie nauki. Bazując na poglądach Druckera, badacze zgodzili się, że główna 
różnica między przedsiębiorcą a właścicielem małej firmy polega na celach i motywacji w dążeniu do realizacji tych celów. Przedsiębiorca został zdefiniowany jako osoba kierująca się zyskiem i posiadająca silną motywację i determinację do realizacji tego celu. Tymczasem właściciel firmy to osoba, której celem jest utrzymanie siebie i swojej rodziny, dzięki prowadzonej działalności gospodarczej (Cieślik, 2010, s. 19).

Pojęcie przedsiębiorczości nabrało nowego wymiaru pod koniec $\mathrm{XX}$ wieku, dzięki rozwojowi nowych technologii, a w szczególności Internetu. Technologie informatyczne pozwolity na rozwój przedsiębiorczości na tak dużą skale, że słowa Schumpetera o twórczej destrukcji branży pod wpływem działań przedsiębiorczych ponownie stały się aktualne. Przykładem może być opracowany przez jednego człowieka - Linusa Torvaldsa - system operacyjny Linux, który w zastosowaniach profesjonalnych, zwłaszcza wśród programistów odebrał część rynku niemal monopolistycznemu standardowi Windows stworzonemu przez międzynarodową korporację Microsoft.

Internet dał jednak przedsiębiorcom znacznie więcej możliwości niż tylko kreowanie innowacyjnego oprogramowania. Przede wszystkim pozwolił na nieograniczone zdobywanie informacji, niemal darmową promocję swojej działalności, budowanie powiązań biznesowych poprzez strony www oraz portale społecznościowe, a także prowadzenie sprzedaży poprzez sklepy i aukcje internetowe. Dzięki Internetowi rozpoczęla się nowa era przedsiębiorczości.

\section{Przedsiebbiorczość w Polsce}

Wbrew obiegowym opiniom, przedsiębiorczość w Polsce ma długą tradycję. W latach 80. XX wieku udział sektora MŚP (zwanego wówczas sektorem drobnej wytwórczości) w zatrudnieniu wynosił $7 \%$. Nie było to wiele, jak na warunki gospodarki wolnorynkowej, jednak pozwoliło na podtrzymywanie kultury przedsiębiorczości i rozwoju przedsiębiorców nazywanych popularnie „prywaciarzami”. Do segmentu drobnej wytwórczości należeli przedstawiciele drobnego handlu, taksówkarze czy rzemieślnicy, którzy cieszyli się dość dużym uznaniem, choć wzbudzali jednocześnie zazdrość w opinii społecznej.
Szczególnie trudne czasy dla polskich przedsiębiorców nastąpiły na początku lat 90. XX wieku, po przemianach ustrojowych w kraju. Reguły, według których funkcjonowały dotychczas biznesy przestały obowiązywać. Z jednej strony w nowej, dopiero kształtującej się gospodarce wolnorynkowej panował chaos. Wprowadzony w życie plan Balcerowicza, nagłe załamanie się olbrzymiego odbiorcy - Związku Radzieckiego, niedostosowanie jakościowe polskich technologii do standardów europejskich i zacofanie organizacyjne kadr kierowniczych spowodowało upadek większości wielkich państwowych firm oraz Państwowych Gospodarstwach Rolnych (PGR-ów). Pozbawiło to ludzi środków do życia, a rynku siły nabywczej. Z drugiej zaś - okres ten otworzył możliwości zakładania własnej działalności, choć sytuacja z jaką mierzyli się przedsiębiorcy końca XX wieku nie była komfortowa. Wystarczy podać tu choćby silną dewaluacje złotówki, galopująca inflacje, wprowadzenie nieznanych wcześniej rozwiązań podatkowych, jak podatek VAT, wchodzenie do Polski zachodnich przedsiębiorstw znacznie bardziej doświadczonych, posiadających nowoczesne technologie, kapitał, profesjonalne umiejętności zarządzania. $\mathrm{Z}$ tego powodu polskie przedsiębiorstwa w tamtym czasie rozrastały się i bankrutowały często $z$ „dnia na dzień”, nikt wówczas nie miał ani doświadczenia, ani wiedzy, jak prowadzić firmę w tak nieprzewidywalnych warunkach.

Mimo tych przeszkód przedsiębiorczość po roku 90. zaczęła się intensywnie rozwijać. W 1990 roku liczba podmiotów gospodarczych wynosiła 1,2 mln, a w 2012 roku sięgnęła $4 \mathrm{mln}$. Niezmiernie istotne w tych analizach jest jednak to, że 99,8\% wszystkich przedsiębiorstw w Polsce stanowią dziś małe i średnie przedsiębiorstwa.

Choć dynamika wzrostu przedsiębiorczości w Polsce jest wysoka, to już nie można tego samego powiedzieć o innowacyjności polskich przedsiębiorców. Według Komisji Europejskiej, oceniającej innowacyjność krajów członkowskich UE „Innovation Union Scoreboard", Polska należy do grupy najmniej innowacyjnych krajów europejskich. Zdaniem ekspertów, jest to m.in. efekt niskiego poziomu zaangażowania w działalność innowacyjną firm, zwłaszcza z sektora MSP (Raport, Innovation Union Scoreboard, 2014). 
Próbą zmierzenia się z tym problemem jest opracowana, w styczniu 2013 r., na zlecenie Ministerstwa Gospodarki Strategia Innowacyjności i Efektywności Gospodarki „Dynamiczna Polska 2020”. Strategia ta określa kierunki działań, jakie powinny zostać podjęte, aby polska gospodarka w perspektywie do 2020 r. osiągnęła dobre wyniki. Szczególną uwagę poświęca się sektorowi MŚP. Do najważniejszych obszarów priorytetowych, według tego dokumentu, którymi powinien zająć się rząd należy:

1) stworzenie warunków, w których przedsiębiorcy mogą dobrze prosperować, a przedsiębiorczość jest nagradzana;

2) zagwarantowanie, by uczciwi przedsiębiorcy, których przedsiębiorstwo zostało postawione w stan upadłości, dostali drugą szansę;

3) przygotowanie regulacji zgodnie z zasadą „MŚP przede wszystkim”;

4) zapewnienie odpowiedniej reakcji organów administracji publicznej na potrzeby MŚP;

5) dostosowanie instrumentów realizowanych rodzajów polityki do potrzeb MŚP: ułatwienia MSP udziału w zamówieniach publicznych oraz wykorzystanie możliwości pomocy państwa dla MŚP;

6) ułatwienie MŚP dostępu do finansowania i rozwijanie otoczenia prawnego i biznesowego w zakresie realizacji terminowych płatności w transakcjach handlowych;

7) wspieranie MŚP w lepszym korzystaniu z możliwości oferowanych przez Wspólny Rynek;

8) wspieranie podnoszenia kwalifikacji w MSP i wszelkich form innowacji;

9) umożliwienie MŚP przekształcania wyzwań związanych z ochrona środowiska na nowe możliwości rozwoju;

10) zachęcanie i wspieranie MSP w czerpaniu korzyści z dostępu do rynków.

Na podstawie powyższych strategicznych wskazań zostały opracowane następujace rekomendacje do konkretnych zadań, jakie stoja przed Ministerstwem Gospodarki:

- eliminacja lub zmiana przepisów wprowadzających nadmierne obciążenia administracyjne, finansowe i sprawozdawcze;

- uproszczenie oraz zapewnienie przejrzystości systemu podatkowego;

- dostęp do kapitału we wszystkich fazach rozwoju przedsiębiorstw;

- dostęp MŚP do pomocy publicznej;
- uproszczenie procedur pozyskiwania środków z funduszy europejskich;

- stymulowanie innowacyjności wśród przedsiębiorców.

\section{Czynniki utrudniające rozwój przedsiębiorczości w Polsce w świetle badań}

Konfederacja pracodawców Lewiatan corocznie wydaje publikację informującą o czynnikach utrudniajacych rozwój przedsiębiorczości w Polsce. W świetle badań prowadzonych przez tę organizację do głównych czynników hamujących przedsiębiorczość należą (Lewiatan, 2014) bariery:

1) ogólnogospodarcze utrudniające prowadzenie działalności gospodarczej,

2) wynikające ze stosunków pracy,

3 ) podatkowe,

4) w wykorzystaniu funduszy strukturalnych,

5) z zakresu ochrony środowiska,

6) branżowe.

W szczególności raport Lewiatana wskazuje na:

- zbyt wysokie podatki i składki na ubezpieczenia społeczne; dodatkowo niejasne przepisy podatkowe prowadzą do licznych konfliktów między przedsiębiorcami a organami skarbowymi;

- zbyt sztywne, jak na obecny poziom rozwoju gospodarczego, prawo pracy; w Polsce elastyczność rynku pracy ma większe znaczenie niż w krajach Europy Zachodniej; wg raportu Polska może zwiększyć swoją konkurencyjność w Europie, jeżeli zliberalizuje prawo w taki sposób, by pozostawiać pracodawcy więcej swobody w negocjowaniu czasu pracy pracownika, warunków zatrudniania, zwalniania oraz wynagradzania pracowników, dostosowując warunki do własnej kondycji finansowej;

- niedopasowanie systemu edukacji do bieżących potrzeb i trendów gospodarki; w szczególności chodzi tu o bardzo niski poziom kwalifikacji tzw. miękkich u absolwentów szkół, czyli umiejętności komunikacji i pracy zespołowej; brakuje również wykwalifikowanych kadr z umiejętnościami zawodowymi;

- niska efektywność procedur związana z zamówieniami publicznymi; raport podkreśla przede wszystkim niskie kwalifikacje zespołów odpowiedzialnych za przegotowanie zamówień w instytucjach 
państwowych oraz cenę jako kluczowe kryterium warunkujące wygranie przetargu;

- nieefektywne prawo i organy prawne; w szczególności bariera tkwi w przewlekłym i kosztownym procesie dochodzenia należności oraz nieefektywnym procesie upadłości;

- niskiej efektywności wykorzystania pomocy finansowej ze środków UE Lewiatan upatruje w nadmiernej biurokracji, bałaganie informacyjnym oraz braku nastawienia pro klienckiego przez instytucje zaangażowane w przyznawanie dotacji.

Na tle wniosków, jakie prezentuje raport Lewiatana, warto przyjrzeć się co sądzą na temat czynników wspierających i utrudniających rozwój przedsiębiorczości przedsiębiorcy z małego polskiego miasta.

\section{Badanie przedsiębiorczości w Polsce}

Badania czynników wpływających i ograniczających przedsiębiorczość w MŚP zostały przeprowadzone w Tomaszowie Mazowieckim (województwo łódzkie) na
79 firmach $\mathrm{z}$ regionu w 2013 r. Osobami ankietowanymi byli właściciele firm lub osoby zajmujące stanowiska kierownicze. Podział badanych według wielkości firm przedstawia rysunek 1 .

Wśród badanych najwięcej odpowiedzi na ankiety nadesłały mikroprzedsiębiorstwa zatrudniające do 10 pracowników $(66 \%)$; na drugim miejscu były przedsiębiorstwa małe zatrudniające do 49 pracowników $(29 \%)$.

Biorąc pod uwagę branże - największą grupę badanych stanowiły firmy produkcyjne $(37 \%)$ oraz budowlane, a także firmy handlowe $(31 \%)$, następnie zaś usługi finansowe i biznesowe, np. usługi IT, ochrona (19\%).

W badaniu czynników sprzyjających bądź utrudniających prowadzenie biznesu ankietowani mieli ocenić 10 czynników i odpowiedzieć czy według nich w przyszłości czynniki te staną się zagrożeniem, czy szansą dla rozwoju ich przedsiębiorstw. Każdy z czynników był opisany skala 5-stopniową, gdzie 5 oznaczało bardzo dużą szanse, a 1 bardzo duże zagrożenie. Odpowiedź 3 wskazywała na brak jednoznacznej opinii.

Rysunek 1. Podział badanych według wielkości firm
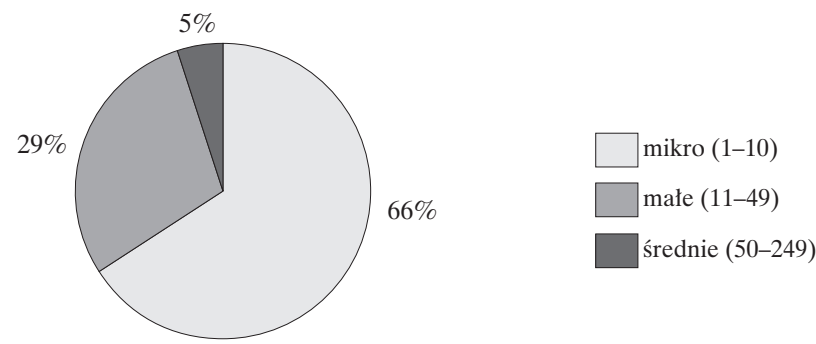

Źródło: opracowanie własne.

Rysunek 2. Podział badanych firm według branż

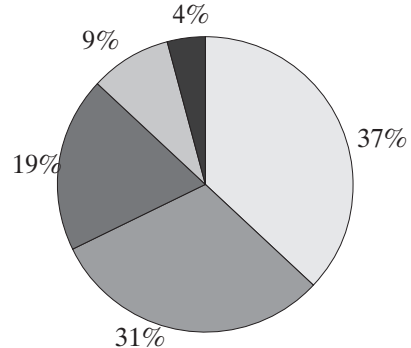

$$
\begin{aligned}
& \square \text { produkcja i budownictwo } \\
& \square \text { handel } \\
& \square \text { usługi finansowe/biznesowe } \\
& \square \text { transport i komunikacja } \\
& \text { usługi drobne (naprawy, remonty) }
\end{aligned}
$$

Źródło: opracowanie własne. 
Rysunek 3. Czynniki sprzyjające i utrudniające rozwój przedsiębiorczości w regionie Tomaszowa Mazowieckiego

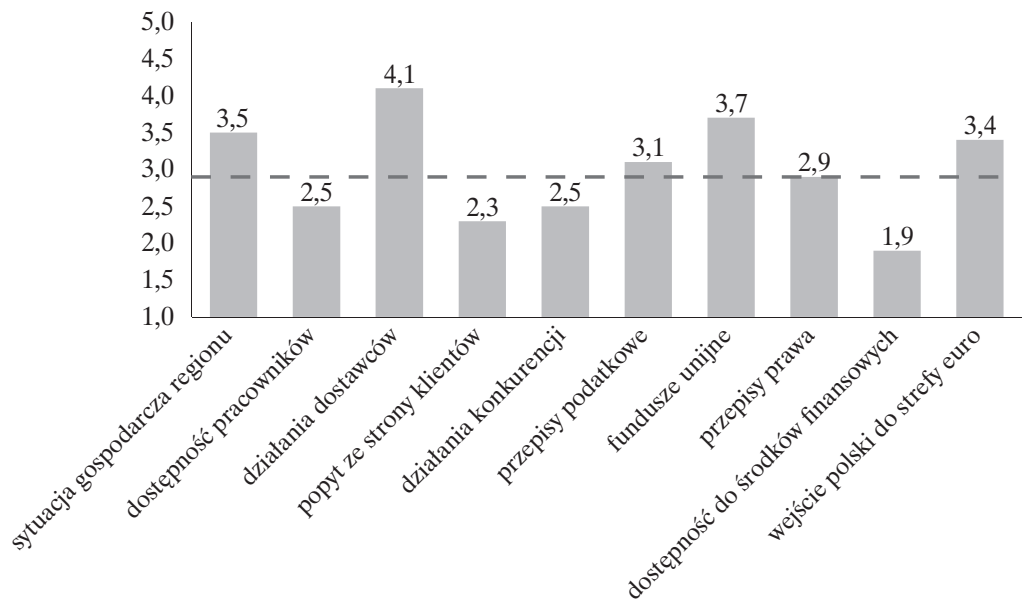

Źródło: opracowanie własne.

Rysunek 4. Przewidywanie zmian przychodów w kolejnym roku

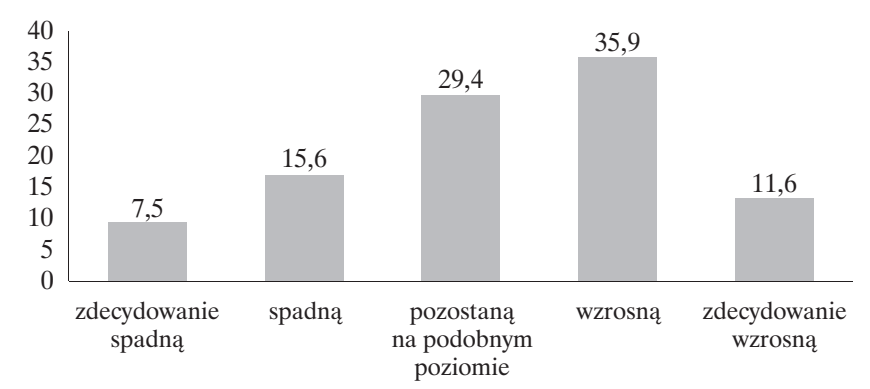

Źródło: opracowanie własne.

Za największą szansę dla rozwoju przedsiębiorstwa ankietowani uznali działania dostawców $(4,1 \%)$, zwłaszcza w zakresie jakości i terminowość dostaw oraz innowacyjność dostarczanych produktów. Dzięki działaniom dostawców przedsiębiorcy widzą szansę na poprawę własnej oferty asortymentowej, poprawę jakości oferowanych produktów i usług, a także obniżke kosztów. Na drugim miejscu (3,7\%) wśród szans uplasował się dostęp do funduszy unijnych, które według ankietowanych istotnie wspieraja rozwój lokalnej przedsiębiorczości. Trzeba tu jednak odnotować, że choć przedsiębiorcy uznają fundusze za szansę na rozwój gospodarczy przedsiębiorstw w regionie, to, jak przyznają sami, znaczna część $\mathrm{z}$ nich nie korzysta $\mathrm{z}$ tej formy wsparcia (zob. rys. 5). Jako trzeci najważniejszy czynnik sprzyjający szansom na rozwój przedsiębiorcy wymienili sytuację gospodarcza regionu, która odbierana jest przez nich jako dość sprzyjająca $(3,5 \%)$. Pewne nadzieje wiąża też $\mathrm{z}$ wejściem Polski do strefy euro, przy czym większymi optymistami w tej kwestii są przedsiębiorcy mający doświadczenie w eksporcie i imporcie produktów $(3,4 \%)$.

Biorąc pod uwagę główne zagrożenia, przedsiębiorcy w największym stopniu wskazuja na trudności w dostepie do środków finansowych. Uznają ten czynnik za kluczową barierę utrudniająca rozwój własnych przedsiębiorstw (1,9\%). Za drugie najważniejsze zagrożenie uważają ograniczony popyt ze strony klientów. Ograni- 
Rysunek 5. Wykorzystanie zewnętrznych źródet wsparcia finansowego na rozwój działalności gospodarczej

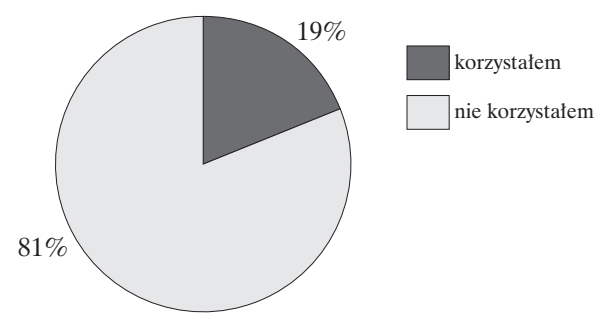

Źródło: opracowanie własne.

czenie to według ankietowanych wynika z sytuacji ekonomicznej odbiorców oraz z działań konkurencji, którą również uważają za dominującą barierę rozwoju $(2,5 \%)$. Jednocześnie bariera jest także dostep do wykwalifikowanej kadry pracowników $(2,5 \%)$, co może budzić zaskoczenie, biorąc pod uwagę niemal $19 \%$ bezrobocie w tym regionie.

Za względnie neutralne czynniki dla rozwoju przedsiębiorstw ankietowani uznal przepisy podatkowe $(3,1 \%)$ oraz przepisy prawa $(2,9 \%)$

Mimo umiarkowanego optymizmu przedsiębiorców w zakresie tworzenia szans na rozwój gospodarczy regionu większość z nich optymistycznie prognozuje przyszłe swoje przychody. Blisko $77 \%$ ankietowanych uważa, że w kolejnym roku ich przy- chody nie zmniejszą się. Przy czym 47,5\% z nich uważa, że przychody wzrosną, a $30 \%$, że pozostaną na niezmienionym poziomie.

$\mathrm{Na}$ tle deklaracji związanych $\mathrm{z}$ trudnościami finansowymi uniemożliwiającymi rozwój firmy ciekawie wyglądają wyniki badań dotyczące zdobywania wsparcia finansowego na rozwój działalności gospodarczej.

Dominująca większość - 81\% ankietowanych zadeklarowała, że nie korzystała z żadnych źródeł zewnętrznej pomocy finansowej. Pozostała część najczęściej wykorzystywała środki pochodzące ze źródeł unijnych.

Powodami, dla których przedsiębiorcy nie korzystali ze źródeł pomocy publicznej była niekorzystna opinia na temat stopnia skomplikowania procedur i formularza wniosku o udzielenie wsparcia finansowego $(32 \%)$. Ankietowani twierdzili również, że nie rozumieją oczekiwań podanych w dokumentach o przyznanie dofinansowania i nie potrafią samodzielnie wypełnić tych dokumentów. Nie są również w stanie, z racji czasu $(15 \%)$, wnikać w zawiłości wyjaśnień rozbudowanej dokumentacji wnioskowej. Jednocześnie dla $13 \%$ z nich skorzystanie z zewnętrznego wsparcia przy wypełnianiu dokumentów oceniane było jako zbyt drogie i obarczone zbyt wysokim ryzykiem, że dofinansowanie nie zostanie im przyznane. Blisko 1/3 udzielających odpowiedzi przyznała, że nie korzysta z dofinansowania, gdyż programy te nie są dostosowane do specyfiki branż czy przedsiębiorstw, które prowadzą.

Rysunek 6. Czynniki utrudniające korzystanie z zewnętrznej pomocy finansowej

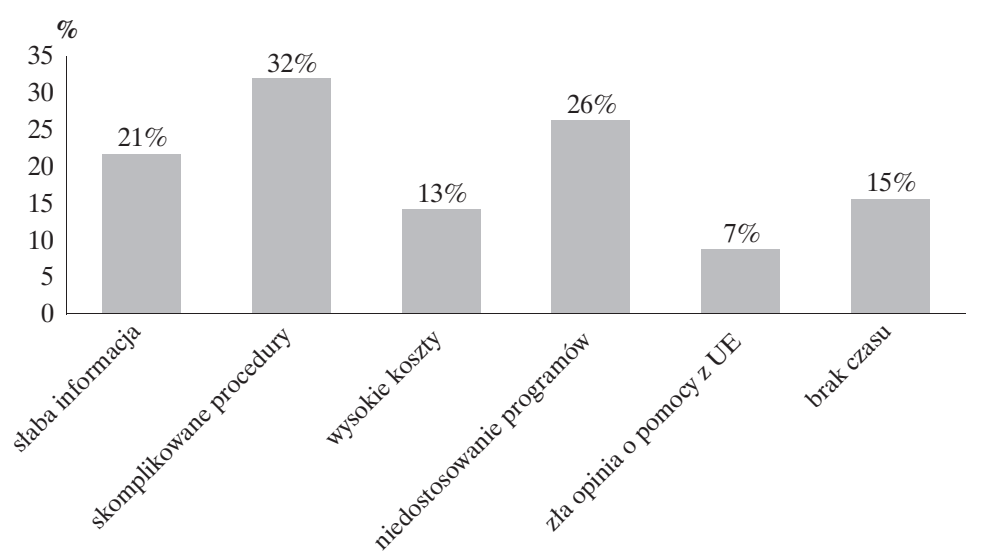

Źródło: opracowanie własne.

Wydział Zarządzania UW DOI 10.7172/1733-9758.2014.17.2 
Rysunek 7. Wiedza dotycząca źródet finansowania

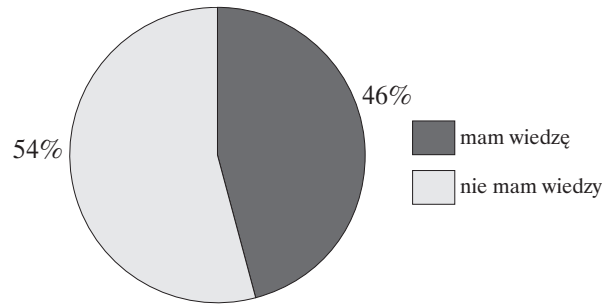

Źródło: opracowanie własne.

Ponad 54\% ankietowanych przyznało, że nie posiada wiedzy na temat możliwych źródeł finansowania. Najczęściej jako powód takiej sytuacji wymieniali, że nie mieli potrzeby poszukiwania takich informacji lub nie wiedzieli gdzie jej szukać. Odpowiedzi te wyglądają szczególnie ciekawie na tle informacji udzielanych przez respondentów, że główna bariera rozwoju ich biznesu jest brak środków finansowych.

W odpowiedzi na pytanie, jakie działania ze strony władz miasta mogłyby pomóc przedsiębiorcom w rozwoju ich działalności ankietowani wskazywali jak na rysunku 8.

Do głównych czynników, będących w gestii władz miasta, które pomogłyby wesprzeć rozwój przedsiębiorczości w regionie ankietowani zaliczyli ulgi w podatkach i opłatach (68\%), a także uproszczenie procedur i skrócenie czasu zakładania firm $(63 \%)$. Ponadto ponad połowa badanych przyznała, że wszelkie formy dofinansowywania działalności przez miasto pomogłyby im w rozwoju własnych przedsiębiorstw i przyczyniłyby się do rozwoju gospodarczego regionu. Jednocześnie przedsiębiorcy nie widzą znaczącej potrzeby w organizowaniu przez władze lokalne szkoleń, ponieważ większość $\mathrm{z}$ nich nie widzi potrzeby uczestniczenia w nich. Przedsiebbiorcy, których działalność ma charakter sezonowy za szczególnie ważne uznali możliwość zawieszania działalności na okres poza sezonem.

\section{Podsumowanie}

Biorąc pod uwage wybrane obszary Strategii Innowacyjności i Efektywności Gospodarki „Dynamiczna Polska 2020” oraz bariery rozwoju przedsiębiorczości opracowane przez konfederację Lewiatan warto przyjrzeć się im przez pryzmat opinii przedsiębiorców z małego polskiego miasta, jakim niewątpliwie jest Tomaszów Mazowiecki.

Jedno z kluczowych zadań opisanych w strategii dotyczy ułatwienia MŚP dostępu do finansowania, w tym uproszczenie procedur pozyskiwania środków $\mathrm{z}$ funduszy europejskich. Głównym punktem wspólnym prowadzonych badań przez autorke oraz konfederację Lewiatan jest to, że dostęp do środków finansowych według przedsiębiorców jest główną barierą rozwoju przedsiębiorczości. Jednocześnie wiedza przedsiebiorców na temat możliwości pozyskania

Rysunek 8. W jaki sposób władze lokalne mogą pomóc w rozwoju przedsiębiorczości

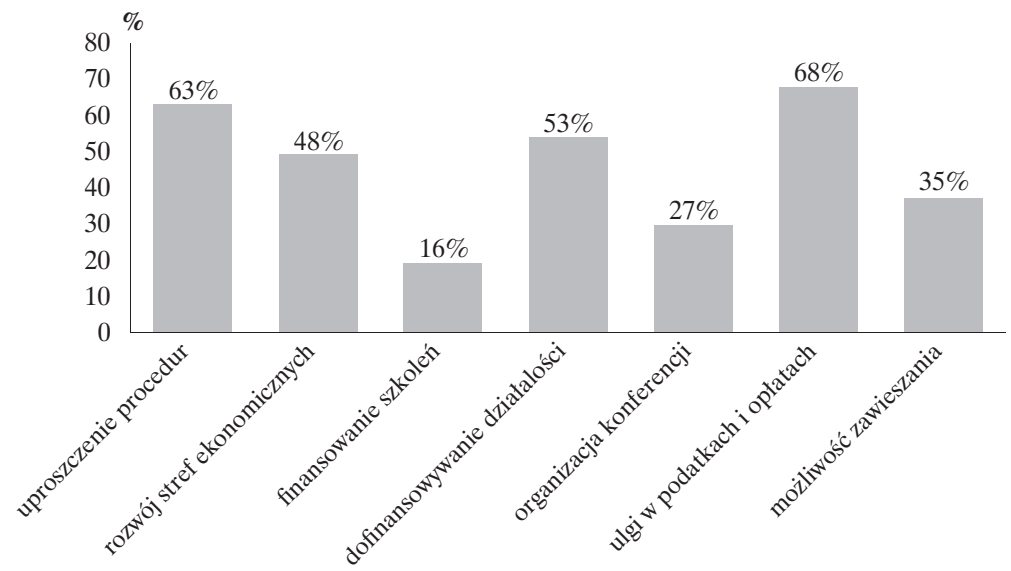

Źródło: opracowanie własne. 
środków oraz umiejętności i zrozumienie procedur zdobywania środków jest na bardzo niskim poziomie. Wynika z tego, że oprócz uproszczenia procedur działania władz państwowych i lokalnych powinny być nastawione na uświadamianie przedsiębiorców poprzez kampanie informacyjne i szkolenia. Tymczasem zarówno z niniejszych, jak i z szeroko dostępnych badań na temat przedsiębiorczości wynika, że przedsiębiorcy nie mają potrzeby uczestniczenia w szkoleniach i nie poszukuja aktywnie informacji na temat możliwości rozwoju swoich biznesów, w tym poszukiwania źródeł finansowania. Czyli wyniki badań wskazuja na dość patową sytuację. Występuje także zbieżność wniosków obu badań co do bariery wynikającej z nadmiernych obciążeń fiskalnych.

Co zatem powinna zrobić administracja lokalna, by wpłynąć na wzrost aktywność przedsiębiorców i sprzyjać im w usuwaniu barier rozwoju biznesu? Wnioski nasuwają się następujące:

- należy intensywniej informować przedsiębiorców o możliwościach, jakie tkwią w programach unijnych oraz w krajowych programach wsparcia MSP; przy czym konieczne jest tu wsparcie ze strony wykwalifikowanego personelu, który nie tylko poinformuje przedsiębiorców o istnieniu programów, lecz także udzieli im pomocy w zakresie wypełnienia właściwych wniosków oraz przejścia przez całą procedurę ubiegania się o to wsparcie; badania wskazują na umiarkowane zadowolenie przedsiębiorców z kompetencji osób odpowiedzialnych za doradztwo w tej dziedzinie;

- warto stosować ulgi w podatkach oraz dofinansowanie niektórych wydatków dla tych przedsiębiorstw, które dopiero rozpoczynają działalność oraz dla tych, które starają się rozwijać działalność poprzez inwestowanie w ryzykowne przedsięwzięcia; takim dofinansowaniem powinno się objąć zarówno zakup nowoczesnych technologii, jak i zatrudnianie nowych pracowników - np. stażystów, bezrobotnych, absolwentów szkól;

- powinno sie także uprościć procedury załatwiania spraw w urzędach; przedsiębiorcy uważają, że załatwienie spraw trwa za długo, jest zbyt skomplikowane, a urzędnicy powinni być bardziej pomocni.

\section{Bibliografia}

Cieślik, J. (2010). Przedsiębiorczość dla ambitnych. Jak uruchomić wtasny biznes. Warszawa: Wydawnictwa Akademickie i Profesjonalne Spółka z o.o.

Lewiatan (2014). Czarna lista barier dla rozwoju przedsiębiorczości. Warszawa.

Drucker, P. (1992). Innowacja i przedsiębiorczość, Praktyka i zasady. Warszawa: PWE.

Kortan, J. (red.) (1997). Podstawy ekonomiki i zarzadzania przedsiębiorstwem. Warszawa: Wydawnictwo C.H. Beck.

Marek, S. (red.) (1998). Podstawy ekonomiki przedsiębiorstw. Szczecin: Zrzeszenie Studentów Polskich.

Potocki, A. (red.) (2000). Wspótczesne tendencje w zarzadzaniu - teoria i praktyka. Chrzanów: Wyższa Szkoła Przedsiębiorczości i Marketingu w Chrzanowie.

Raport, Innovation Union Scoreboard, 2014. Pozyskano z: http://ec.europa.eu/enterprise/policies/ innovation/files/ius/ius-2014_en.pdf (15.06.2014).

Schumpeter, J. (1960). Teoria rozwoju gospodarczego. Warszawa: PWN. 